\title{
Publisher Correction: Mediator complex interaction partners organize the transcriptional network that defines neural stem cells
}

Marti Quevedo', Lize Meert ${ }^{1}$, Mike R. Dekker ${ }^{1}$, Dick H.W. Dekkers², Johannes H. Brandsma', Debbie L.C. van den Berg (1) ${ }^{1}$, Zeliha Ozgür ${ }^{3}$, Wilfred F.J. van IJcken (10 ${ }^{3}$, Jeroen Demmers ${ }^{2}$, Maarten Fornerod ${ }^{1} \&$ Raymond A. Poot ${ }^{1}$

Correction to: Nature Communications https://doi.org/10.1038/s41467-019-10502-8, published online 17 June 2019.

The original version of this Article contained an error in the spelling of the author Wilfred F. J. van IJcken, which was incorrectly given as Wilfred F. J.van IJcken. This has now been corrected in both the PDF and HTML versions of the Article.

Published online: 22 July 2019

(c) (i) Open Access This article is licensed under a Creative Commons Attribution 4.0 International License, which permits use, sharing, adaptation, distribution and and indicate if changes were made. The images or other third party material in this article are included in the article's Creative Commons license, unless indicated otherwise in a credit line to the material. If material is not included in the article's Creative Commons license and your intended use is not permitted by statutory regulation or exceeds the permitted use, you will need to obtain permission directly from the copyright holder. To view a copy of this license, visit http://creativecommons.org/licenses/by/4.0/.

(c) The Author(s) 2019

\footnotetext{
${ }^{1}$ Department of Cell Biology, Erasmus MC, Wytemaweg 80, 3015 CN Rotterdam, Netherlands. ${ }^{2}$ Center for Proteomics, Erasmus MC, 3015 CN Rotterdam, Netherlands. ${ }^{3}$ Center for Biomics, Erasmus MC, 3015 CN Rotterdam, Netherlands. Correspondence and requests for materials should be addressed to R.A. P. (email: r.poot@erasmusmc.nl)
} 